\title{
KUALITAS DAN PALATABILITAS SILASE DAUN MANGROVE PADA TERNAK DOMBA EKOR GEMUK
}

\section{THE QUALITY AND PALATABILITY OF MANGROVE LEAVES ON FAT- TAILED SHEEP LIVESTOCK}

\author{
Yasmini Suryaningsih \\ Email : Jasminumsambac95@gmail.com \\ Agribisnis, Pertanian, Universitas Abdurachman Saleh Situbondo
}

\begin{abstract}
ABSTRAK
Tujuan dari penelitian ini adalah mengevaluasi kualitas silase daun mangrove yang diberikan pada ternak domba ekor gemuk serta mengevaluasi palatabilitas silase daun mangrove pada ternak domba ekor gemuk. Penelitian ini terdiri dari tiga tahap yaitu tahap pembuatan silase sesuai dengaan rancangan perlakuannya tahap uji kualitas silase dan tahap palatabilitas silase. Hasil dari penelitian ini adalah proses fermentasi daun mangrove menjadi silase mampu mempertahankan kualitas fisiknya khususnya pada tekstur daun sedangkan Palatabilitas domba terhadap pakan silase daun mangrove sangat rendah.

Kata Kunci : Silase, Palatabilitas, Domba Ekor Gemuk
\end{abstract}

\begin{abstract}
The purpose of this study is to evaluate the quality of mangrove leaf silage given to fat-tailed sheep livestock and evaluate the palatability of mangrove leaf silage on fat-tailed sheep livestock. This study consisted of three stages, namely the stage of making silage according to the design of the treatment stage of the silage quality test stage and the silage palatability stage. The results of this study are the process of fermentation of mangrove leaves into silage is able to maintain its physical quality, especially in the texture of the leaves while the palatability of sheep against mangrove leaf silage feed is very low. Keywords: Silage, Palatability, Fat Tailed Sheep
\end{abstract}

\section{PENDAHULUAN}

Pakan merupakan salah satu faktor penentu utama yang mempengaruhi keberhasilan suatu usaha peternakan. Ketersediaan bahan pakan ternak akhir-akhir ini semakain terbatas. Hal ini disebabkan antara lain oleh meningkatnya harga bahan baku pakan, karena semakin menyusutnya lahan bagi pengembangan produksi hijauan akibat penggunaan untuk keperluan pangan, dan tempat pemu- 


\section{Volume 3 , Nomor 2,}

Desember 2019

kiman serta pembangunan industri. Oleh karena itu, perlu dicari sumber daya baru yang mampu menggantikan sebagian atau seluruh hijauan serta dapat mengurangi ketergantungan pada penggunaan bahan konsentrat yang sudah lazim digunakan. Bahan tersebut seyogyanya tersedia pada suatu tempat dalam jumlah banyak, sehingga untuk memperolehnya tidak membutuhkan biaya besar. Berbagai macam jenis tanaman yang hijau sepanjang tahun dapat dimanfaatkan sebagai hijauan pakan seperti daun mangrove (Krisna, 2017), kaliandra dan lain sebagainya termasuk juga daun tanaman mangrove yang melimpah di daerah pantai.

Potensi yang dimiliki oleh daun mangrove sebagai sumber hijauan pakan ternak ditunjukkan oleh kandungan protein, serat, karbohidrat dan mineral ( $\mathrm{Fe}$, $\mathrm{Mg}, \mathrm{Ca}, \mathrm{K}, \mathrm{Na}$ ) dalam jumlah yang cukup tinggi (Wibowo, 2009).Daun Mangrove juga memiliki potensi sebagai obat herbal hal ini dilaporkan oleh Kustanti (2011) bahwa beberapa jenis mangrove yang daunnya bisa dimakan, dapat menyembuhkan beberapa penyakit seperti rematik, penyakit kulit, kanker dan mengobati asma, bahkan menurut Danata dan Ade (2014) serta Santosa dkk. (2015) daun mangrove dapat menghambat pertumbuhan bakteri penyakit. Potensi tersebut menyebabkan peternak juga mampu menjaga kondisi kesehatan ternak mereka sehingga kondisi ternak terserang penyakit dapat ditekan.

Ketersediaan daun mangrove sebagai pakan ternak sangat berlimpah dan ketersediannya berkesinambungan sepanjang tahun. Namun demikian pada saat musim hujan yang terus menerus, terjadi hambatan dalam memanfaatkan daun mangrove sebagai hijauan pakan karena keadaan hijauan basah sehingga menimbulkan masalah kesehatan ternak seperti kembung, diare. Untuk mengatasi hambatan tersebut, dibutuhkan strategi pengewetan hijauan pakan untuk menyediakan sumber pakan cadangan melalui teknologi Silase.

Silase merupakan metode pengawetan hijauan pakan ternak dalam bentuk segar yang melalui proses fermentasi anaerob. Pembuatan silase dibagi menjadi dua periode untuk melihat kandungan pakannya. Dengan metode tersebut, pemanfaatan daun mangrove yang ketersediannya berlimpah sepanjang musim dapat di awetkan dan dapat digunakan pada saat peternak tidak sempat untuk 


\section{Volume 3 , Nomor 2,}

meramban atau pada musim-musim tertentu dengan jangka waktu penyimpanan yang lama. Selain itu fungsi nutritive yang terkandung didalam daun mangrove diharapkan dapat dipertahankan melalui proses silase sehingga pada saat musim paceklik pakan silase daun mangrove dapat digunakan sebagai hijauan ternak yang mempunyai kandungan nutritive dengan kualitas baik.

Berdasarkan uraian di atas, permasalahan yang bisa diangkat adalah bagaimanakah Kualitas Silase Daun Mangrove yang diberikan pada Ternak Domba Ekor Gemuk? serta bagaimanakah Palatabilitas Silase Daun Mangrove Pada Ternak Domba Ekor Gemuk?

\section{METODE PENELITIAN}

Penelitian dilakukan di Desa Semiring Kecamatan Mangaran Kabupaten Situbondo pada bulan Oktober - Nopember 2017. Daun mangrove diambil dari hutan mangrove yang tersebar di sepanjang pantai Desa Semiring. Proses pembuatan silase serta uji Palatabilitas dilakukan di peternakan domba ekor gemuk tradisional desa Semiring Kecamatan Mangaran Kabupaten Situbondo.

\section{Materi Penelitian}

Bahan yang digunakan dalam penelitian ini adalah, daun mangrove, dedak halus (akselerator), EM4 (starter) dan domba ekor gemuk jantan. Daun mangrove yang digunakan adalah daun mangrove yang dapat dikonsumsi oleh ternak (edible portion) yaitu daun mangrove muda. Bahan yang digunakan sebagai starter adalah EM4 (Efective Microorganisme) yang efektif digunakan sebagai starter fermentasi bahan pakan ternak. Untuk evaluasi palatabilitas digunakan 4 ekor domba ekor gemuk jantan umur rata-rata10 bulan dengan bobot badan rata-rata $40 \mathrm{~kg}$.

Alat yang digunakan selama penelitian ini adalah kandang individu sebanyak 4 unit dengan ukuran $1 \mathrm{~m} \times 1,5 \mathrm{~m}$, timbangan untuk menimbang pakan dengan kepekaan $0,1 \mathrm{~kg}$ kapasitas $5 \mathrm{~kg}$, timbangan analitik dan timbangan untuk menimbang bobot badan Domba dengan kepekaan 0,1 kg kapasitas $150 \mathrm{~kg}$, toples sebagai wadah atau silo pada pembuatan silase, ember dan pisau untuk mencacah daun mangrove yang akan dijadikan silase. 


\section{Volume 3 , Nomor 2,}

Desember 2019

Penelitian ini terdiri dari tiga tahap yaitu tahap pembuatan silase sesuai dengaan rancangan perlakuannya tahap uji kualitas silase dan tahap palatabilitas silase.

\section{Tahap Pembuatan Silase Daun Mangrove Perlakuan \\ a. Jenis silase perlakuan}

Pada tahap ini dilakukan pembuatan 3 jenis silase (P0, P1, P2) dengan bahan utama daun mangrove. Adapun ke 3 jenis silase tersebut adalah:

P0 : Silase daun Mangrove tanpa bahan tambahan

P1 : Silase daun Mangrove ditambah dengan 6\% dedak

P2 : Silase daun Mangrove ditambah dengan 6\% dedak dan 1\% starter EM4 Masing-masing silase dibuat 2x4 ulangan (8 toples). Masing-masing ulangan terrsebut digunakan untuk mengevaluasi kualitas silase dengan perbedaan lama ensilase 14 dan 21 hari.

\section{b. Pembuatan Silase}

Pada pembuatan silase digunakan daun mangrove sebanyak $\pm 150 \mathrm{~kg}$ yang diambil pada pagi hari. Selanjutnya daun mangrove yang telah diambil dicacah dengan ukuran $\pm 5 \mathrm{~cm}$. Hasil cacahan ditimbang dengan berat masing-masing 1,5 $\mathrm{kg}$ dan ditempatkan pada 6 toples untuk perlakuan P0. Untuk perlakuan P1, cacahan daun mangrove ditimbang sebanyak $3 \mathrm{~kg}$ dan ditempatkan dalam baskom, setelah itu ditambah dengan 180 g dedak halus (6\%), dan diaduk hingga merata. Selanjutnya dibagi menjadi dua bagian dengan berat $\pm 1,5 \mathrm{~kg}$ dan dimasukkan kedalam 2 toples. Proses yang sama diulang untuk 4 toples berikutnya. Selanjutnya untuk perlakuan P2, cacahan daun mangrove ditimbang sebanyak $3 \mathrm{~kg}$ yang ditempatkan kedalam baskom, setelah itu ditambah dengan $180 \mathrm{~g}$ dedak halus (6\%) lalu diaduk hingga merata lalu ditambah lagi dengan 30 ml EM4 (1\%) kemudian diaduk kembali. Selanjutnya dibagi menjadi 2 bagian dengan berat $\pm 1,5 \mathrm{~kg}$ dan dimasukkan kedalam 2 toples. Proses diulang untuk 4 toples berikutnya.

Setelah semua bahan dimasukkan kedalam toples, toples ditutup rapat agar keadaan anaerob dapat tercapai. Adapun prosedur pembuatan silase dapat dilihat 


\section{Volume 3 , Nomor 2,}

pada gambar 1. Setelah semua bahan dimasukkan kedalam toples, toples ditutup rapat agar keadaan anaerob dapat tercapai. Adapun prosedur pembuatan silase dapat dilihat pada gambar 1 .

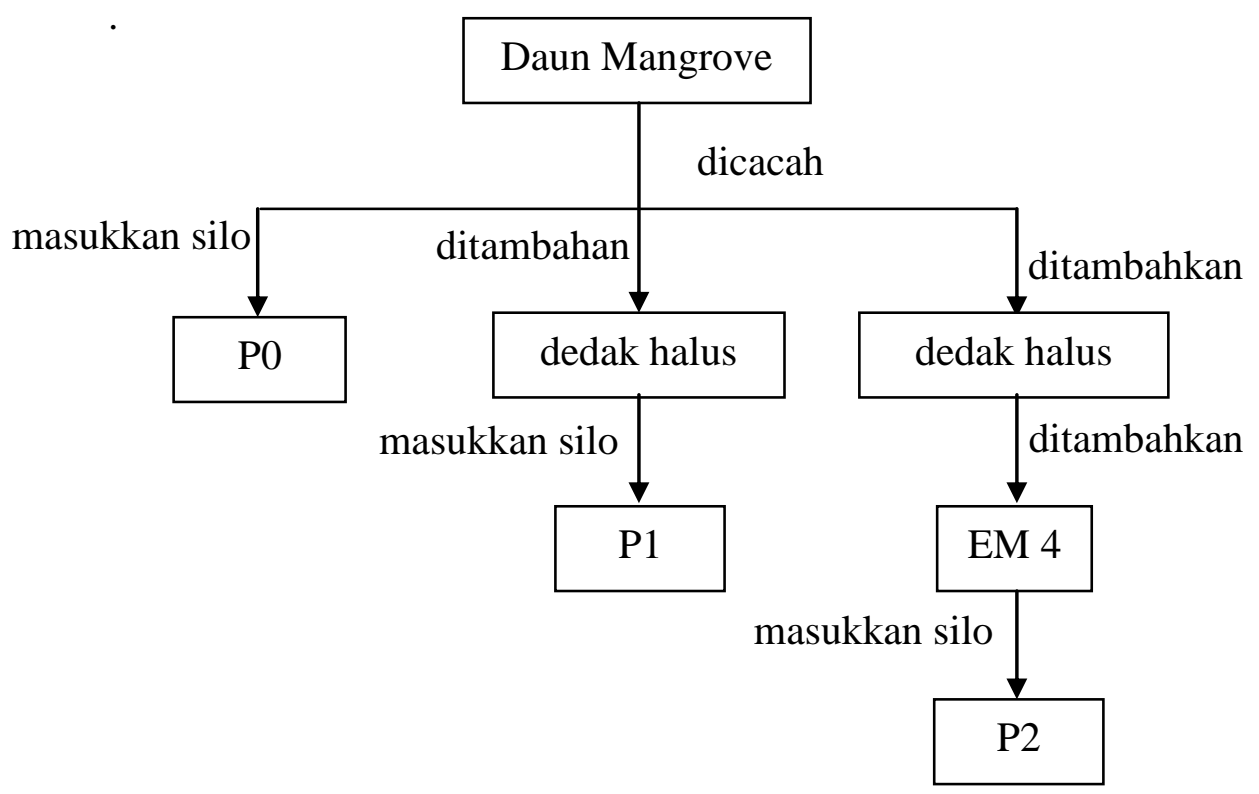

Gambar 1. Prosedur Pembuatan Silase

Pada hari ke 14 dan 21 setelah proses fermentasi ensilase, masing-masing silase diambil sampelnya sebanyak $100 \mathrm{~g}$ untuk uji kualitas fisik, $\mathrm{pH}$ dan temperatur dari sampel masing masing perlakuan

\section{c. Uji kualitas fisik dan $\mathbf{p H}$}

1. Kualitas Fisik

Kualitas fisik silase daun mangrove dilakukan dengan mengamati karakter fisik silase seperti warna (hijau kekuningan, coklat, coklat kehitaman), aroma (busuk, asam, sangat asam), tekstur (menggumpal, tidak menggumpal) Cullison (1975) dan Utomo (1994). Selanjutnya tempratur silase didalam silo diukur pada akhir proses ensillase, yaitu pada hari ke 14 dan 21 untuk semua jenis silase. Alat yang digunakan untuk pengukuran adalah termometer batang. 


\section{Volume 3 , Nomor 2,}

2. Nilai $\mathrm{pH}$

Pengukuran nilai $\mathrm{pH}$ silase menggunakan prosedur Naumann dan Bassler (1997). Sebanyak $10 \mathrm{~g}$ silase dicampur dengan $100 \mathrm{ml}$ aquades dan dimasukkan ke dalam blender selama 1 menit dengan kekuatan sedang. Setelah itu, $\mathrm{pH}$ meter yang sudah ditera terhadap larutan standar ber-pH 4 dan $\mathrm{pH} 7$ dimasukkan ke dalam sampel dan dilakukan pembacaan $\mathrm{pH}$ setelah 30 detik atau setelah $\mathrm{pH}$ terlihat stabil.

\section{d. Variabel yang Diamati}

Adapun variabel yang diamati adalah :

1. Kualitas fisik silase (aroma, tekstur, dan warna) dan tempratur akhir silase.

2. Nilai $\mathrm{pH}$ serta temperatur silase umur 14 dan 21 hari

\section{e. Analisis Data}

Pada penelitin ini data kualitas fisik, $\mathrm{pH}$ dan temperaturyang diamati secara deskriptif.

\section{Tahap Evaluasi Palatabilitas Silase}

\section{a. Metode Evaluasi}

Evaluasi tingkat kesukaan (palatabilitas) ternak terhadap silase yang dihasilkan dilakukan menggunakan silase yang ensilasenya berlangsung selama 21 hari. Ketiga jenis silase tersebut diberikan pada 4 ekor ternak domba ekor gemukjantan.

Jenis perakuan pakan untuk uji palatabilitas silase terdiri dari :

DS :` Daun Mangrove Segar

P0 :' Silase daun ranting mangrove segar tanpa bahan tambahan

P1 `' Siase daun ranting mangrove segar ditambah dengan $6 \%$ dedak

P2 : Siase daun ranting mangrove segar ditambah dengan $6 \%$ dedak dan $1 \%$ starter EM4

Metode evaluasi palatabilitas yang digunakan adalah metode kafetaria menurut afdal, et a., (2012). Jumlah pakan yang diberikan didasarkan pada intake bahan kering ternak menurut Wigati, et al., (2016) yaitu 5\% dari bobot badan. 


\section{Volume 3 , Nomor 2,}

Desember 2019

Bila rata-rata bobot badan Domba $30 \mathrm{~kg}$, maka jumlah intake yang dibutuhkan adalah 2000 g. Total Silase yang diberikan pada ternak sebanyak $60 \%$, sehingga masing-masing jenis silase (P0, P1, dan P2) yang diberikan adalah $20 \%$ yang dibagi dalam 3 kali pemberian (6.7\%) yaitu pada pukul 08.00, 11.00 dan 14.00. Daun mangrove segar (DK) diberikan sebanyak 20\% dari total kebutuhan yang dibagi dalam 3 kali pemberian pukul 08.00, 11.00 dan 14.00. Untuk 20\% sisa kebutuhan diberikan campuran dari beberapa hijauan pakan lain selain daun mangrove seperti, rumupt kawatan (Otochloa nodosa), rumput paitan (Axonopus compresus), anggrung, daun nangka, rumput cabe-cabean, gusduran dan lainnya. Sebelum perlakuan dimulai ternak diadaptasikan dahulu dengan ke 3 jenis silase selama 3 hari.

Adapun metode evaluasi palatabilitas silase yang dilakukan adalah sebagai berikut.

1. Untuk metode kafetaria ini digunakan 4 ekor domba yang masing masing ditempatkan didalam kandang individu

2. Daun mangrove segar dan masing-masing jenis silase ditimbang sebanyak 300 g (BK basis) dan masing-masing jenis pakan perlakuan tadi dibagi menjadi 3 bagian yaitu masing-masing 100 g. Selanjutnya bahan kering tersebut dikonversikan kedalam bahan segar berdasarkan nilai BK silase.

3. Keempat jenis pakan perlakuan tersebut kemudian diberikan kepada masingmasing ternak secara bersamaan dan penentuan tempat pakan dilakukan secara acak.

4. Frekuensi pemberian pakan adalah 3 kali sehari yaitu pada pukul 08.00, 11.00 dan 14.00. Pada setiap periode pemberian pakan, penentuan tempat pakan akan kembali diacak. Penimbangan sisa pakan dilakukan setiap akhir periode pemberian pakan. Kemudian dihitung kosumsi pada setiap periode pemberian dengan menggunakan rumus sebagai berikut :

konsumsi $\mathrm{BK}=$ jumlah $\mathrm{BK}$ - BK sisa pakan

5. Data konsumsi bahan kering pada setiap periode pemberian pakan akan dipresentasikan dalam bentuk dipersentasikan dalam tabel jumlah konsumsi 


\section{Volume 3 , Nomor 2,}

Desember 2019

yang juga akan digunakan untuk mengevaluasi palatabilias ternak terhadap jenis pakan perlakuan.

\section{b. Rancangan Percobaan}

Rancangan yang digunakan untuk evaluasi Palatabilitas adalah Rancangan Acak Lengkap (RAL) dengan 4 perlakuan (DK, P0,P1, P2,) dan 16 ulangan (4 ulangan ternak dan 4 ulangan hari).

\section{c. Variabel Yang Diukur}

Variabel yang diukur adalah palatabilitas ternak terhadap pakan perlakuan yang diukur dari tingkat preferensi dan jumlah total rata-rata konsumsi bahan kering. Preferensi diukur dari jumlah konsumsi jenis pakan yang paling banyak dikonsumsi pada setiap periode penyajian. Total konsumsi dihitung dari jumlah konsumsi masing-masing jenis hijauan pakan dari total periode pemberian pakan.

\section{d. Analisis Data}

Data konsumsi pada tiap pemberian yang mengindikasikan preferensi ternak terhadap jenis hijuan pakan akan dianalisis secara deskriftif. Data rata-rata konsumsi pakan dianalisi dengan analisis variansi (ANOVA) sesuai dengan rancangan percobaanya. Bila ada pengaruh yang nyata dari perlakuan akan dilanjutkan dengan Uji Jarak Duncan (steel and Torrie, 1993).

\section{HASIL DAN LUARAN YANG DICAPAI}

\section{Karakteristik Fisik Silase Daun Mangrove}

Indikator keberhasillan silase dapat dilihat dari kualitas silase yang dihasilkan. Hal itu dapat dilihat dari karakteristik silase yang dihasilkan yang merupakan salah satu faktor yang dapat mempengaruhi kualitas silase (Bolsen dan Sapienza 1993). Hasil pengamatan karakteristik (warna, aroma, tekstur,) silase daun mangrove dapat dilihat pada Tabel 1. 


\section{Volume 3 , Nomor 2,}

Desember 2019

Tabel 1. Hasil Pengamatan Karakteristik Silase Daun Mangrove

\begin{tabular}{|c|c|c|c|c|}
\hline \multirow[t]{2}{*}{ Perlakuan } & \multicolumn{4}{|c|}{ Peubah yang Diamati } \\
\hline & Warna & Aroma & Tekstur & Umur \\
\hline $\mathrm{P}_{0}$ & Hijau Kecoklatan & - & $\begin{array}{l}\text { kering, tidak mudah } \\
\text { patah }\end{array}$ & \\
\hline $\mathrm{P}_{1}$ & Hijau Kekuningan & - & $\begin{array}{l}\text { kering, tidak mudah } \\
\text { patah }\end{array}$ & 14 Hari \\
\hline $\mathrm{P}_{2}$ & Hijau Kekuningan & - & $\begin{array}{l}\text { kering, tidak mudah } \\
\text { patah }\end{array}$ & \\
\hline $\mathrm{P}_{0}$ & coklat & $\begin{array}{l}\text { Agak } \\
\text { Asam }\end{array}$ & $\begin{array}{l}\text { lembab, kaku, tidak } \\
\text { mudah patah }\end{array}$ & \\
\hline $\mathrm{P}_{1}$ & Hijau Kecoklatan & $\begin{array}{l}\text { Agak } \\
\text { Asam }\end{array}$ & $\begin{array}{l}\text { lembab, kaku, tidak } \\
\text { mudah patah }\end{array}$ & 21 Hari \\
\hline $\mathrm{P}_{2}$ & Hijau Kecoklatan & Asam & $\begin{array}{l}\text { lembab, kaku, tidak } \\
\text { mudah patah }\end{array}$ & \\
\hline
\end{tabular}

Berdasarkan pengamatan karakteristik yang telah dilakukan, dapat dikatakan bahwa seluruh silase perlakuan mempunyai kualitas fisik yang baik yakni mempunyai warna hijau, hijau kekuningan atau kecoklatan, beraroma asam dan bertekstur secara umum masih jelas sepertialaminya. (Utomo, 1999 dan Siregar, 1996).

Warna coklat pada perlakuan P0 berbeda dengan perlakuan lainnya, hal ini diduga karenapemadatan yang kurang sempurna padahampir semua silo yang digunakan sehinggamasih terdapat kantong-kantong udara yangcukup besar. Menurut Reksohadiprodjo(1988) perubahan warna yang terjadi padatanaman yang mengalami proses ensilase disebabkan oleh perubahan-perubahan yangterjadi dalam tanaman karena prosesrespirasi aerobik yang berlangsung selamapersediaan oksigen masih ada, sampai gulatanaman habis. Gula akan teroksidasimenjadi CO2 dan air, dan terjadi panashingga temperatur naik. Bila temperatur takdapat terkendali, silase akan berwarnacoklat tua sampai hitam. Hal inimenyebabkan turunnya nilai makanan,karena banyak sumber karbohidrat yanghilang dan kecernaan protein turun, yaitupada temperatur 55oC. 


\section{Volume 3 , Nomor 2,}

Desember 2019

\section{Karakteristik Fermentasi Silase}

Karakteristik fermentasi menjadi indikator fermentasi. Karakteristik fermentasi silase yang diamati meliputi nilai $\mathrm{pH}$ dan temperatur silase .

\section{a. Nilai pH}

Nilai $\mathrm{pH}$ merupakan salah satu indikator kualitas silase. Besaran nilai $\mathrm{pH}$ silase daun mangrove dengan lama ensilase dapat dilihat pada tabel 2.

Tabel 2. pH Silase Daun Mangrove

\begin{tabular}{cccc}
\hline \multirow{2}{*}{ Perlakuan } & \multicolumn{2}{c}{ Lama Ensilase (Hari) } & \multirow{2}{*}{ Rerata } \\
\cline { 2 - 3 } & $\mathbf{1 4}$ & $\mathbf{2 1}$ & \\
\hline $\mathbf{P}_{\mathbf{0}}$ & $\mathbf{5 , 7 5}$ & $\mathbf{5 , 5 0}$ & $\mathbf{5 , 6 3}$ \\
$\mathbf{P}_{\mathbf{1}}$ & $\mathbf{6 , 0 0}$ & $\mathbf{5 , 5 0}$ & $\mathbf{5 , 7 5}$ \\
$\mathbf{P}_{\mathbf{2}}$ & $\mathbf{5 , 0 0}$ & $\mathbf{4 , 0 0}$ & $\mathbf{4 , 5 0}$ \\
\hline Rerata & $\mathbf{5 , 5 8}$ & $\mathbf{5 , 0 0}$ & \\
\hline Keterangan & $:$ P0 $=$ silase daun mangrove tanpa bahan tambahan. & \\
& P1 $=$ silase daun mangrove + dedak $6 \%$. \\
& P2 $=$ silase daun mangrove + dedak $6 \%+$ EM4 $1 \%$. & \\
&
\end{tabular}

Tabel diatas menunjukkan bahwa terdapat perbedaan $\mathrm{pH}$ pada lama ensilase 14 dan 21 hari dengan rerata $\mathrm{pH}$ berturut turut yaitu 5,58 dan 5,00. Perbedaan tersebut menunjukkan adanya penurunan $\mathrm{pH}$ pada umur ensilase 21 hari dibandingkan dengan ensilase 14 hari, hal ini terjadi karena pada ensilase 14 hari proses fermentasi masih berlangsung. Hal ini sesuai dengan pernyataan Elfering (2010) yakni pada fase fermentasi terjadi proses reaksi anaerob. Fase ini berlangsung dari beberapa hari hingga beberapa minggu, tergantung dari komposisi bahan dan kondisi silase. Jika proses fermentasi berjalan sempurna, maka bakteri asam laktat sukses berkembang. 


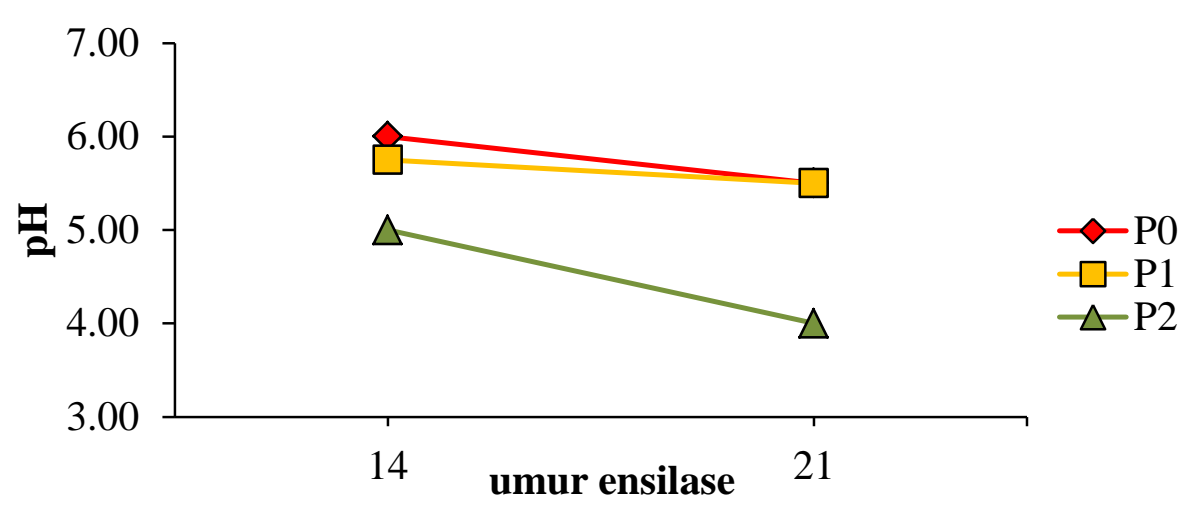

Gambar 2. pH Silase Daun Mangrove pada umur ensilase ke-14 dan 21 hari.

Grafik diatas menunjukkan Penurunan pH silase pada umur ensilase 21 hari dibandingkan dengan ensilase 14 hari terjadipada semua perlakuan. Perlakuan P0 menunjukkan memiliki $\mathrm{pH}$ paling tinggi diantara 2 perlakuan lainnya, dilanjutkan P1 dan yg paling rendah adalah P2 baik pada ensilase 14 hari maupun 21 hari. Hal tersebut terjadi diduga karena pada P2 dan P1 terdapat penambahan dedak dan EM4 yang mengandung karbohidrat dan bakteri asam laktat, sehingga dapat mempercepat penurunan $\mathrm{pH}$ silase karena pembentukan bakteri asam laktat akan terjadi lebih cepat. Pernyataan ini didukung oleh Santoso (2009) yang menjelaskan dengan penambahan bakteri asam laktat dan sumber karbohidrat dapat mempercepat laju fermentasi dan mempercepat penurunan $\mathrm{pH}$ dengan memanfaatkan monosakarida seperti glukosa dan fruktosa sehingga terjadi akumulasi asam laktat. Sedangkan pada silase P0 yang mengalami penurunan $\mathrm{pH}$ secara lambat diduga karena bahan silase daun mangrove rendah akan karbohidrat sehingga sumber karbohidrat hanya berasal dari daun mangrove itu sendiri sehingga pembentukan bakteri asam laktat berjalan lambat. Kualitas silase menurut Stefani et al. (2010) tergantung dari kecepatan fermentasi membentuk asam laktat, sehingga dalam pembuatan silase terdapat beberapa bahan tambahan yang biasa diistilahkan sebagai additive silage. Pemilihan bakteri asam laktat sangat penting dalam proses fermetasi untuk menghasilkan silase yang berkualitas baik. Proses awal dalam fermentasi asam laktat adalah proses aerob, udara yang berasal dari lingkungan 


\section{Volume 3 , Nomor 2,}

atau pun yang berasal dari hijauan menjadikan reaksi aerob terjadi. Hasil reaksi aerob yang terjadi pada fase awal fermentasi silase menghasilkan asam lemak volatile, yang menjadikan $\mathrm{pH}$ turun.

Ensilase 21 hari mmenunjukkan bahwa kualitas silase berdasarkan nilai $\mathrm{pH}$, dapat dikatakan sangat baik hingga buruk secara berurutan pada perlakuan $\mathrm{P} 2$ $=4,00, \mathrm{P} 1=5,50$, dan $\mathrm{P} 0=5,50$, hal tersebut mengacu pada Wilkins (1998) dan Siregar (1996) yang menyebutkan bahwa kualitas silase berdasarkan $\mathrm{pH}$ dikategorikan menjadi 4 golongan, silase dikatakan baik sekali jika ( $\mathrm{pH} 3,2$-4,2), baik ( $\mathrm{pH} 4,2-4,5)$, sedang ( $\mathrm{pH} 4,5-4,8)$ dan buruk jika $(\mathrm{pH}>4,8)$.

\section{b. Temperatur}

Pada proses fermentasi, temperatur merupakan indikasi pertumbuhan bakteri asam laktat. Sehingga kualitas silase dapat dilihat dari kenaikan dan penurunan temperatur silase. Temperatur silase dapat dilihat pada tabel 3 .

Tabel 3. Temperatur silase $\left({ }^{\circ} \mathrm{C}\right)$

\begin{tabular}{lccc}
\hline Perlakuan & \multicolumn{2}{c}{ Lama Ensilase $($ Hari) } & \multirow{2}{*}{ Rerata } \\
\cline { 2 - 3 } & $\mathbf{1 4}$ & $\mathbf{2 1}$ & \\
\hline $\mathbf{P}_{\mathbf{0}}$ & $\mathbf{3 0 , 7 5}$ & $\mathbf{2 6 , 7 5}$ & $\mathbf{2 8 , 7 5}$ \\
$\mathbf{P}_{\mathbf{1}}$ & $\mathbf{3 0 , 5 0}$ & $\mathbf{2 6 , 5 0}$ & $\mathbf{2 8 , 5 0}$ \\
$\mathbf{P}_{\mathbf{2}}$ & $\mathbf{2 9 , 5 0}$ & $\mathbf{2 6 , 2 5}$ & $\mathbf{2 7 , 8 8}$ \\
\hline Rerata & $\mathbf{3 0 , 2 5}$ & $\mathbf{2 6 , 5 0}$ & \\
\hline Keterangan & $:$ P0 $=$ silase daun mangrove tanpa bahan tambahan. \\
& P1 $=$ silase daun mangrove + dedak 6\%. \\
& P2 $=$ silase daun mangrove + dedak 6\% + EM4 1\%. &
\end{tabular}

Tabel diatas menunjukkan bahwa terdapat perbedaan temperatur pada lama ensilase 14 dan 21 hari dengan rerata temperatur berturut turut yaitu 30,25 dan 26,50. Perbedaan tersebut menunjukkan adanya penurunan temperatur pada umur ensilase 21 hari dibandingkan dengan ensilase 14 hari, hal ini terjadi diduga karena lama ensilase yang berbeda sehingga terjadi perbedaan fase proses fermentsi. Pada awal ensilase, silase memasuki fase aerob dan anaerob, pada fase aerob tempratur akan meningkat. Hal ini terjadi karena tumbuhan masih 


\section{Volume 3 , Nomor 2,}

Desember 2019

mengalami proses respirasi. Kenaikan tempratur tidak akan terjadi jika kondisi anaerob cepat tercapai.

Pada kondisi anaerob bakteri dari permukaan hijauan akan mengkonsumsi oksigen sampai oksigen habis. Proses ini sangat diinginkan pada proses pembuatan silase, di mana dengan habisnya oksigen secara optimal kondisi anaerob dapat segera tercapai. pada waktu yang bersamaan, bakteri-bakteri tersebut akan memanfaatkan karbohidrat terlarut yang seharusnya digunakan bakteri asam laktat (BAL) untuk membentuk asam laktat menjadi CO2, H2O dan panas. Proses ini menyebabkan kehilangan energi dan bahan kering (Muck, 2011), sehingga penurunan suhu terjadi pada lama ensilase 21 hari.

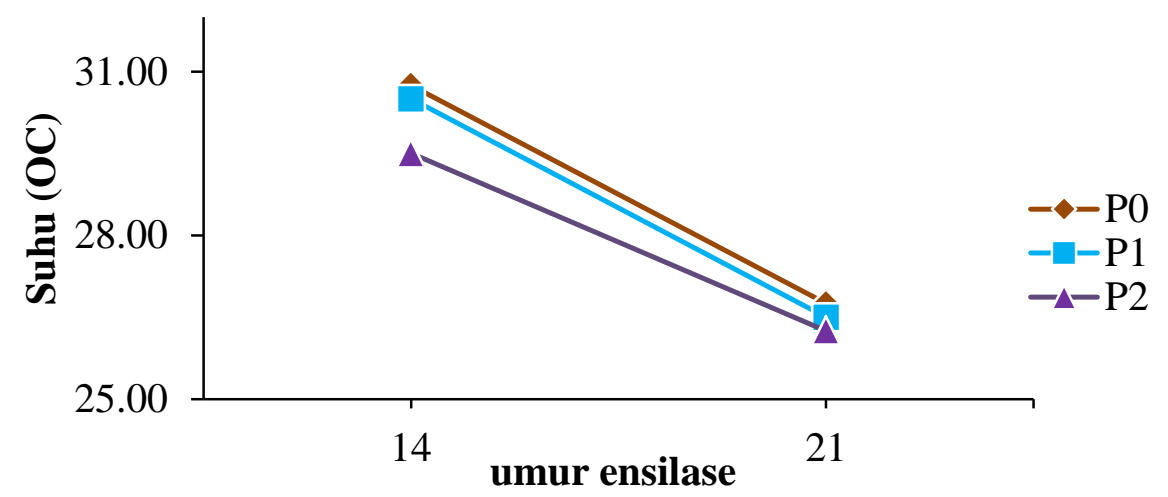

Gambar 3. Grafik Perbedaan Temperatur silase $\left({ }^{\circ} \mathrm{C}\right)$ pada umur ensilase yang berbeda.

Grafik diatas menunjukkan Penurunan temperatur silase pada umur ensilase 21 hari dibandingkan dengan ensilase 14 hari terjadipada semua perlakuan. Perlakuan P0 menunjukkan memiliki temperatur paling tinggi diantara 2 perlakuan lainnya, dilanjutkan P1 dan yg paling rendah adalah P2 baik pada ensilase 14 hari maupun 21 hari. 


\section{Palatabilitas Terhadap Daun Mangrove Segar Dan Silase Perlakuan Pada Domba Ekor Gemuk}

Tabel 4. ANOVA Konsumsi Daun Mangrove Perlakuan

\begin{tabular}{|c|c|c|c|c|c|c|}
\hline \multirow{2}{*}{$\begin{array}{c}\text { Sumber } \\
\text { Keragaman }\end{array}$} & \multirow{2}{*}{$\mathrm{db}$} & \multirow{2}{*}{ JK } & \multirow{2}{*}{ KT } & \multirow{2}{*}{$F_{\text {hit }}$} & \multicolumn{2}{|c|}{$F_{\text {tab }}$} \\
\hline & & & & & 0,05 & 0,01 \\
\hline Perlakuan & 3 & 86369,42 & 28789,81 & $1953,17^{k * *}$ & 14,50 & 5,24 \\
\hline Kelompok & 3 & 12,54 & 4,18 & $0,28^{\text {ss }}$ & 14,50 & 5,24 \\
\hline Galat & 9 & 132,66 & 14,74 & & & \\
\hline Total & 15 & 86514,62 & & & & \\
\hline
\end{tabular}

Tabel 5. Uji Duncan untuk Rerata konsumsi dan prosentase konsumsi pakan perlakuan (gr/ekor/hari)

\begin{tabular}{lcc}
\hline Perlakuan & $\begin{array}{c}\text { Rerata Konsumsi } \\
(\text { gr/ekor/hari })\end{array}$ & $\begin{array}{c}\text { Prosentase Konsumsi Perekor } \\
\text { Perhari }(\%)\end{array}$ \\
\hline $\mathrm{Ms}$ & $198,81^{\mathrm{d}}$ & $59,70^{\mathrm{d}}$ \\
$\mathrm{P}_{0}$ & $4,00^{\mathrm{a}}$ & $1,20^{\mathrm{a}}$ \\
$\mathrm{P}_{1}$ & $54,94^{\mathrm{c}}$ & $16,50^{\mathrm{c}}$ \\
$\mathrm{P}_{2}$ & $20,75^{\mathrm{b}}$ & $6,23^{\mathrm{b}}$ \\
\hline Keterangan & Ms = Daun Mangrove Segar & \\
& $\mathrm{P} 0=$ silase daun mangrove tanpa bahan tambahan. \\
& $\mathrm{P} 1$ = silase daun mangrove + dedak 6\%. \\
& $\mathrm{P} 2=$ silase daun mangrove + dedak 6\% + EM4 1\%. \\
& Perbedaan notasi huruf menunjukkan perbedaan yang sangat nyata
\end{tabular}

Banyaknya jumlah ransum yang dikonsumsi oleh seekor ternak dapat menggambarkan palatabilitas ransum tersebut (Lawrence, 1990).Hasil analisis varians menunjukkan bahwa terdapat perbedaan yang sangat nyata pada palatabilitas domba terhadap jenis pakan yang diberikan dan tidak menunjukkan perbedaan dari keempat domba dalam mengkonsumsi pakan perlakuan (Tabel 5). Perbedaan palatabilitas tersebut ditunjukkan melalui uji lanjutan dengan uji jarak berganda duncan yang menunjukkan bahwa notasi pada masing masing perlakuan berbeda yang berarti bahwa palatabilitas domba terhadap daun mangrove segar (Ms) berbeda dengan silase daun mangrove tanpa bahan tambahan (P0), silase daun mangrove + dedak 6\% (P1) dan silase daun mangrove + dedak $6 \%+$ EM4 $1 \%$ (P2). Begitu juga palatabilitas domba terhadap silase dgn perlakuan P0 


\section{Volume 3 , Nomor 2,}

Desember 2019

berbeda dengan P1 dan P2, serta perlakuan P1 berbeda dengan P2. Perbedaan yang sangat mencolok tersebut juga disajikan dalam bentuk grafik di gambar 4 .

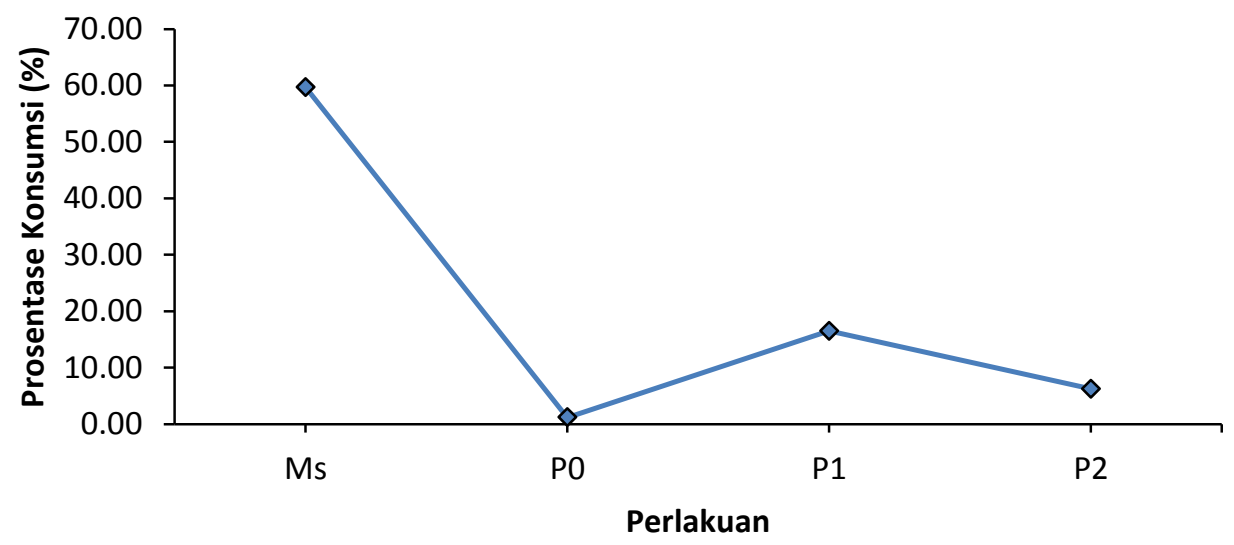

Gambar 4. Perbedaan Prosentase Konsumsi Pakan Perlakuan

Grafik diatas memperlihatkan bahwa bahwa prosentase konsumsi pakan silase jauh lebih rendah dari daun mangrove segar yang berarti bahwa palatabilitas terhadap daun mangrove adalah paling tinggi dari pada pakan silase. Tabel 6 memperlihatkan nilai konsumsi domba terhadap pakan perlakuan yang diberikan, dimana konsumsi pakan daun mangrove segar sebesar 198,8 grekor/hari jauh melebihi konsumsi pakan silase baik P0 (4 gr/ekor/hari), P1 (54,94 gr/ekor/hari) maupun P2 (20,75 gr/ekor/hari). Tingginya konsumsi pada daun mangrove segar diduga karena ternak sudah terbiasa dengan daun mangrove segar yang diberikan, walaupun konsumsi daun mangrove segar hanya 59,70\%. Konsumsi yang rendah ini disebabkan rasa dari daun mangrove segar yang sepat dan agak pahit karena adanya tanin pada daun magrove, Tanin mengandung senyawa gugus hidroksifenolik yang menimbulkan rasa sepat (Cheeke dan Shull, 1985). Sedangkan rendahnya palatabilitas silase daun mangrove diduga karena silase perlakuan menimbulkan bau asam yang menyebabkan ketidaksukaan Domba terhadap silase perlakuan. Hal ini sejalan dengan pernyataan Devendra dan Burns (1994), yang menyatakan bahwa pada umumnya Kambing atau domba merupakan jenis ternak yang mempunyai kebiasaan memilih pakan yang akan dikonsumsinya 


\section{Volume 3 , Nomor 2,}

Desember 2019

dan menurut Dukes (1995) pada ternak ruminansia rangsangan penciuman (bau/aroma) sangat penting untuk mencari dan memilih makanan.

\section{KESIMPULAN DAN SARAN \\ Kesimpulan}

Kesimpulan yang didapat dari penelitian ini adalah sebagai berikut :

1. Proses Fermentasi daun mangrove menjadi silase mampu mempertahankan kualitas fisiknya khususnya pada tekstur daun

2. Palatabilitas domba terhadap pakan silase daun mangrove sangat rendah

\section{Saran}

Saran dari penelitian ini adalah sebagai berikut :

1. Perlu adanya penelitian lanjutan untuk mengetahui perubahan komposisi kandungan kimiawi pada silase daun mangrove

2. Perlu adanya penelitian tentang komposisi dedak dan EM4 yang terbaik ditambahkan pada silase daun mangrove untuk mendapatan silase dengan mutu yang baik.

3. Pemanfaatan daun mangrove sebagai pakan ternak dalam jumlah besar perlu mempertimbangkan kelangsungan ekosistem mangrove di daerah pesisir, oleh sebab itu perlu adanya pemeliharaan dan rehabilitasi ekosistem mangrove oleh masyarakat yang memanfaatkannya.

\section{DAFTAR PUSTAKA}

Afdal.M., K. Azhar,A.R. Alimon and N. Abdullah. 2012. Evaluation of the Palatability of Palm Decanter Meal Preserved with Ground Cinnamon Stick (Cinnamomumburmannii) on Goat. Journal of Animal and Veterinary Advances

Cheeke, P.R. and L.R. Shull. 1985. Tannins and Polyphenolic Compounds. In : Cheeke, P.R. (Ed.) Natural Toxicants in Feed and Poisonous Plant. AVI Publishing Company, Connecticut. USA. 


\section{Volume 3 , Nomor 2,}

Cullison, A. E. 1975. Feed And Feding. University Of George Reston Publishing Company Inc. Virginia.

Devendra, C. dan G. B. McLeroy. 1982. Goat and Sheep Production in the Tropics. Longman. New York.

Dukes, H.H. 1995. the phisycology of Domestic Animal. Ed. Ke - 7. New

Siregar, M.E. 1996. Pengawetan Pakan Ternak. Penebar Swadaya. Jakarta.

Utomo, R. 1999. Teknologi Pakan Hijauan. Fakultas Peternakan, Universitas Gadjah Mada, Yogyakarta.

Wigati, S. Maksudi, dan E. Wiyanto. 2016. The Use of Rubber Leaves (Heveabrasiliensis) as Forage In Suporting The Development of Goats.

Wigati, S., Kustantinah., E. Wiyanto and E. R. Orskov. 2014b. in Sacco Degradability of Six Different Tropical Feedstuffs. Proceedings The 16th AAAP Animal Science Congress :Vol II Abstracts : 1014 November 2014, Yogyakarta, Indonesia.

Wigati, S., M. Maksudi and A. Latief.2014a. Analysis of Rubber Leaf (Hevea brasiliensis) Potency as Herbal Nutrition for Goats. Proccedings the 16thAAAP Congress: Sustainable Livestock Production in The Persperctive of Food Security, Policy, Genetic Resources, and Climate Change. Vol II abstract : 10-14 november 2014, Yogyakarta, Indonesia. 